\title{
Making Method in Girlhood Studies
}

\author{
Claudia Mitchell and Jacqueline Reid-Walsh
}

\section{$\cos 80$}

This is the first issue of Girlhood Studies that we have devoted primarily to method and methodology related to deepening an understanding of girlhood and girls' lives. From the very inception of the journal in 2008 we imagined that there would be themed issues devoted to what we have termed "girl-method" (Mitchell and Reid-Walsh 2009: 214), so as to explore the various approaches to studying girlhood, and especially to make explicit the positionality of feminist researchers writing in academic contexts about girlhood. We frame this project as one that aims to be productive and generative and able to take its place alongside transformative themes in feminist methodology, as we see, for example, in the work of Burt and Code (1995) Changing Methods: Feminists Transforming Practice, and Creese and Frisby (2011) Feminist Community Research. However, even though there has been a rich body of work and a long history of research that addresses the nuances of women researching women, particularly in the area of the autobiographical such as, for example, Ann Oakley's (1981) ground breaking article "Interviewing women: A contradiction in terms," there remain gaps in feminist discourse that concerns itself with a framework to name and explicate method work that seeks to address working with girls, for girls and about girlhood. Making method, then, seems to us to be a useful framing term to talk about methodology and method in the area of girlhood studies. In one sense the term can signal the idea of making in relation to becoming as a feature of the social constructions of girlhood and the highly contextualized question of "Who is a girl anyway?" It also picks up on the idea of claiming and creating an identity as we see in Gerry Bloustien's (2004) notion of girlmaking in her work with adolescent girls and video-making. But it also speaks to the need for alternative approaches to making meaning, and so, as feminist researchers working in this area, we may find ourselves making it up, in much the same way that Oakley and others have done, and, in so 
doing, acknowledging the limitations of more conventional forms of working with qualitative data in social research.

\section{Looking in, looking back, looking forward}

No one ever told us we had to study our lives,

make of our lives a study, as if learning natural history

or music, that we should begin with the simple exercises first

and slowly go on trying

the hard ones, practicing till strength

and accuracy become one with the daring

to leap into transcendence .... (Rich 1978:7)

In this, our first themed issue on methodology and methods, five of the seven articles explicitly take up some aspect of looking back so as to "make of our lives a study." This is work that looks at memory as both phenomenon and method. Historically, the particularized use of the term "memorywork" starts with Frigga Haug and her colleagues (1987) as part of a German feminist collective interested in exploring sexualisation. However, memory methods related to girlhood can embrace a wide variety of genres and media: the literary as we see for example in the scholarship on Tsitsi Dangaremba's post-colonial novel Nervous Conditions (Smith 2000), objectbased and archival work (see Reid-Walsh and Mitchell 2009; Mitchell 2009), and the visual (including film and photography) as we see in the work of Annette Kuhn (1995), Valerine Walkerine (1990) and bell hooks (1994). This work with the visual ranges from memory work writing in relation to family photos, through to more generative uses of visual images as can be seen in Jo Spence's (1986) Putting Myself in the Picture, Jo Spence and Rosy Martin's photo stagings to re-enact portraits of themselves as school girls - not in the way they were depicted in the official school photos of their childhood but how they remembered themselves or wanted to remember themselves, and, of course, Jo Spence and Joan Solomon's (1995) edited volume What Can a Woman Do with a Camera? The issue begins with a guest editorial - a curatorial statement—by Marnina Gonick and Susanne Gannon, and a series of four articles that explore collective biography. Building on Davies and Gannon's (2006) previous work on collective biography, the four articles take us into the project of this collective. (See "Collective Biography: An Introduction.")

Then, Rosalind Hampton and Rachel Desjourdy in "Visible on Our Own Terms: Evoking Girlhood Self-Images Through Photographic SelfStudy" present excerpts from their experiences of photographic self-study, 
drawing on two bodies of research - the work of Jo Spence, Annette Kuhn and bell hooks in working with family photographs, and the work of researchers focusing on teachers and self-study. In their article they highlight the possibilities of this method of photographic self-study as "a malleable, feminist approach to critical reflexive practice." In their individual self-studies they explore embodiment: Rosalind's work focuses on what she sees to be the tensions surrounding her racialized identity and her ignorance about the black half of her mixed-race ancestry, while Rachel writes about being born with ectrodactyly-ectodermal dysplasia (cleft syndrome) and becoming hearing-impaired as a result of this. She is seen to be disabled not because she cannot hear but because of how she looks. They meet in a university classroom where Rosalind is the Teaching Assistant and Rachel the student, and come together in an intergenerational project through their shared interest in photographic self-study. As they note: "Photographic self-study engages the power of looking and challenges its practitioner to see and know herself in a different ways, generating critical reflexivity as well as a sense of agency. It meets a key goal of anti-colonial feminist approaches (Anderson, Khan and Reimer-Kirkham 2011) in providing tools for recognizing and better understanding the multiple shifting identities and related intersecting experiences of marginalization and oppression ...."

The final two articles in this issue of GHS while not focused specifically on method draw on approaches and new sites for study that give rise to new questions about methods and tools for studying girlhood, particularly in terms of girl communities. Valerie Friesen, in her article "Discourses of Agency and Gender in Girls' Conversations on Sport in Windhoek, Namibia” engages a group of adolescent girls involved in an after-school program in Namibia in a feminist focus group in which they reflect on body and sport. Her use of feminist focus groups (see Montell 1999) challenges traditional focus group methods, particularly in the context of blurring the boundaries between the researcher and the researched. Friesen's interest in how girls position themselves in relation to the broad Sport for Peace and Development movement is framed within a careful consideration of the Protocol for Gender and Development that was signed by Namibia and the countries of the South African Development Community (SADC) "with the goal of 50/50 male/female representation in member parliaments by 2015." To study the girls' perspectives, Friesen uses discourse analysis as she explores issues of agency, power, and gender in the girls' conversations.

Finally, Szucs, in her article, "Sex Talk Online: Sexual Self-Construction in Adolescent Internet Spaces" explores the ways in which online environ- 
ments provide educational information about sexuality and sexual health to girls and young women. By exploring both the editorial/educational content produced by those who manage the site and what the girls themselves reveal, the author draws attention to the ways in which there is what she terms "a structural division between the conversational boards and the informational pages." Szucs argues that "it is precisely this confusion and uncertainty that serves as a discursive basis on which the community of girls as possible sexual subjects becomes constructed. Girls' uncertainty with sex-related topics initiates long conversations that offer the opportunity to open up the issues of sexuality for various re-interpretations."

The review section of this issue of GHS begins with Martha Hoffman's review of an art exhibition, "Angels \& Tomboys: Girlhood in 19th-Century American Art." Hoffman notes that although "the exhibit takes a strong stance that girls were seen as 'angelic, passive and domestic' and labels girls acting outside those norms as 'transgressive' and as 'tomboys' ... there is a great deal within the exhibit itself to challenge that dichotomy and offer a much richer and less constrained sense of the life of girls." The exhibition took place at Newark Museum in New Jersey, from 12 September 2012 to 6 January 2013, but can be viewed later in the year at the Memphis Brooks Museum of American Art and the Crystal Bridges Museum of American Art.

The issue ends with two book reviews. Kristine Alexander reviews Miriam Forman-Brunell's 2009 book Babysitter: An American History. As she points out in this wide-ranging review, this book "is a social and cultural history of work, gender, and generational conflicts, and also of girls' own responses and agency." Her discussion of the ways in which Forman-Brunell demonstrates just how much "the history of babysitting is also the history of adults' efforts to limit girls' autonomy," makes Alexander's review interestingly appropriate to this issue.

Terri Doughty reviews Michelle J. Smith's 2011 book Empire in British Girl' Literature and Culture: Imperial Girls, 1880-1914. Of special significance here, is her discussion of how Smith addresses "the production and reproduction of imperial values and empire, and girls' print culture, identifying the ways in which girls' work for empire is delineated within the fields of racial mothering, the promotion of both moral and physical health, and the development of skills and strength of character to thrive, if necessary, in colonial settlements."

What is clear is that this cannot be a once-off issue; Girlhood Studies 6:1 is meant to be a starting point in the exploration of a broad range of tools and approaches in future issues of this journal. We thank our guest editors 
Marnina Gonick and Susanne Gannon for their special section on collective biography, and of course all our contributors and reviewers for their work in the project of making method. We look forward to exploring method work in such areas as intersectionality studies and reflexivity studies, ethics, participatory action research, arts-based inquiry, and online ethnographies, to name only some of the possibilities for future issues of Girlhood Studies in the critical study of making method.

\section{References}

Bloustien, Gerry. 2004. Girl-Making. New York: Berghahn Books.

Burt, Sandra, and Lorraine Code. eds. 1995. Changing Methods: Feminists

Transforming Practice. Peterborough, ON: Broadview Press.

Creese, Gillian, and Wendy Frisby. eds. 2011. Feminist Community Research: Case Studies and Methodologies. Vancouver: UBC Press.

Davies, Bronwyn, and Gannon, Susanne. 2006. Doing Collective Biography: Investigating the Production of Subjectivity. Maidenhead, Berkshire [England]: Open University Press.

Haug, Frigga, Sunne Andresen, Anke Bunz-Elfferding, Kornelia Hauser, Ursel Lang, Marion Laudan, Magret Ludemann, and Ute Meir. 1987. Female Sexualization: A Collective Work of Memory. Trans. E. Carter. London: Verso. hooks, bell. 1994. "In our glory': Photography and Black Life." Pp. 43-53 in Picturing Us: African American Identity in Photography, ed. Deborah Willis. New York: The New York Press.

Kuhn, Annette. 1995. Family Secrets: Acts of Memory and Imagination. London and New York: Verso.

Mitchell, Claudia, and Jacqueline Reid-Walsh. 2008. "Girl Method: Placing GirlCentred Research Methodologies on the Map of Girlhood Studies." Pp. 214-233 in Roadblocks to Equality: Women Challenging Boundaries, ed. Jeffrey Klaehn. Montreal: Black Rose Books.

Mitchell, Claudia. 2010. "Things, Objects and Gendered Consumption in Childhood Studies." Pp. 94-112 in Childhood and Consumer Culture, ed. David. Buckingham and Vebjorg Tingstad. London: Palgrave.

Montell, Frances. 1999. "Feminist Focus Group Interviews: A New Feminist Method." NWSA Journal, 11, no. 1: 44-71.

Oakley, Ann. 1981 "Interviewing Women: A Contradiction in Terms." Pp. 3061 in Doing Feminist Research, ed. Helen Roberts. London: Routledge and Kegan Paul. 
Reid-Walsh, Jacqueline, and Claudia Mitchell. 2009. "Doll-Play: A Study of Canadian Girlhood.” Pp. 109-129 in Depicting Canadian Childhood, ed. Loren L. Lerner. Waterloo: Wilfred Laurier University Press.

Rich, Adrienne. 1978. "Transcendental Etude." P.7 in The Dream of a Common Language: Poems 1974-77. New York: W.W. Norton.

Smith, Ann. 2000. "Girl Power in Nervous Conditions: Fictional Practice as a Research Site." McGill Journal of Education 35, no. 3: 245-260.

Spence, Jo. [1986] 1988. Putting Myself in The Picture: A Political, Personal and Photographic Autobiography. Seattle: The Real Comet Press.

Spence, Jo, and Rosy Martin. 1988. "Phototherapy: Psychic Realism as a Healing Art." Ten 8, no. 30: 2-17.

Spence, Jo, and Joan Solomon, eds. 1995. What Can a Woman Do With a

Camera? Photography for Women. London: Scarlett Press.

Walkerdine, Valerie. 1990. Schoolgirl Fictions. London: Virago. 